\title{
Bioengineering systems for protection and improvement of urbanized areas of coastal and recreational zones
}

\author{
Saligadzhi Kurbanov ${ }^{1, *}$, Akhmed Sozaev ${ }^{1}$, Astemir Shogenov ${ }^{1}$, and Abduvali Karshiev ${ }^{2}$ \\ ${ }^{1}$ Kabardino-Balkarian State Agricultural University named after V. M. Kokov, Lenin Avenue, 1V, \\ 360030 Nalchik, Russia \\ ${ }^{2}$ Tashkent State Agrarian University, Universitetskaya, 2, 100140 Kibray district, Tashkent region, \\ Republic of Uzbekistan
}

\begin{abstract}
The problems of protection and environmental management of disturbed and urbanized areas of coastal and recreational zones are urgent for the southern regions of Russia. Exogenous natural processes, intensively developing in the basins of small rivers of mountain zones, pose dangerous situations for populated areas and tourist centers. The applied methods of controlling exogenous processes require ecologization and adaptation to the natural environment. Engineering systems are required to solve the complex problem of reliable protection of urbanized and recreational areas and restoration of disturbed land areas. Bioengineering systems, interconnected structures, which effectively perform engineering and biological functions of protecting territories and restoring disturbed lands have to be developed. For scientific substantiation of proposed bioengineering systems, theoretical and experimental research methods were used, as well as scientific and technical achievements in the fight against exogenous natural processes. The main study results are new constructive and technological solutions for environmental bioengineering systems in disturbed areas of coastal and recreational zones. In compliance with the regulatory requirements for environmental technologies, protective and regulatory structures and slope fastenings have been developed, forming bioengineering systems. Theoretical foundations and recommendations for the design and construction of bioengineering systems for river bed regulation, protection and restoration of disturbed lands in protected areas have been developed. For further studies, scientific, technical and technological foundations for the development of bioengineering protective systems from the proposed structures have been developed. In the future, technical conditions and projects of standard structures of protective and regulatory structures will be developed.
\end{abstract}

\section{Introduction}

The North Caucasus and the South of Russia are known for their wonderful natural conditions and amazing natural monuments. At the same time, the entire infrastructure of

${ }^{*}$ Corresponding author: Kurbanov-salih@rambler.ru 
regions is located in the basins of small rivers. The total length of areas exposed to hazardous effects of natural exogenous processes reaches several hundred kilometers. The annual damage reaches hundreds of billions of rubles. There is a serious issue of protection and environmental management of coastal and recreational zones. This issue is relevant for many countries of the world $[1,2,3]$. Exogenous natural processes, intensively developing in the basins of small rivers of mountain zones, pose dangerous situations for populated areas and tourist centers.

The applied methods of controlling exogenous processes require ecologization and adaptation to the natural environment. Special engineering systems are required to solve the complex problem of reliable protection of urbanized and recreational areas and restoration of disturbed land areas. That is, they should simultaneously perform both engineering and biological functions for protection and restoration of water protection and recreational zones $[4,5]$.

Tourism development and urbanization are capturing new territories, including water conservation and recreational ones. There was a need for environmental regulation and environmental management of disturbed areas of coastal and recreational zones $[6,7,8]$.

The practice of recent decades shows the technogenic nature of the methods used to control exogenous processes, negatively affecting nature. The need emerged for effective and biopositive designs of protective and regulatory structures that form protective bioengineering systems. For this, the authors have developed a protection concept of coastal and recreational zones, where the main emphasis is on the development of bioengineering systems $[9,10]$. Scientific foundations and recommendations for the design and construction of bioengineering systems for river bed regulation, protection and restoration of disturbed lands in protected areas have been developed.

Protective and regulatory structures are used to regulate river reaches and protect coastal and eroded lands. They are widespread and extended structures that have a great impact on the river and coastal zone ecosystems [11, 14, 15]. Engineering solutions have been developed for the construction of protective and regulatory structures and fastenings of a biopositive design based on the use of local materials, which is positively taken by the natural environment, and form bioengineering systems [9, 12, 13, 16-24].

Experimental studies of biopositive designs on rivers prove their reliability and environmental efficiency.

\section{Materials and Methods}

Today, protective and regulatory structures and fastenings are built without taking into account the alluvial and hydrobiological regimes of small rivers, as well as soil and landscape conditions of mountain recreational zones, their remoteness from transport communications and industrial zones. There are no scientifically based methods, regulatory and technical recommendations for the design and construction of effective and reliable structures for bioengineering systems used to regulate channels and protect coastal and recreational zones.

There are methods to protect the natural environment [6] based on natural mechanisms of self-regeneration of environmental elements (rivers, lakes, reservoirs, soil layer, etc.). The use of bioengineering systems and technologies to accelerate natural processes for the restoration of disturbed lands is not considered. A unified theory and evidence-based recommendations are required. At present, the authors are developing theoretical foundations and conditions for development of bioengineering systems. According to the Ecological Doctrine of the Russian Federation, the issues of environmentally friendly methods for engineering protection of territories are considered as a priority [13, 14]. 
To develop complex bioengineering systems, the authors have prepared a list of effective and biopositive designs and fastenings from their own innovative developments and scientific achievements of recent years [16-24]. On the basis of many years of research and developments on the stated topic, the authors have received more than 30 patents and published more than 25 scientific articles. Table 1 shows brief descriptions and diagrams of some structures and their elements (protected as inventions and useful models) for development of bioengineering systems for the protection and restoration of coastal, eroded and other disturbed land areas in recreational zones.

More detailed field and analytical studies were performed on areas of small rivers in urbanized and tourist zones:

- reliability and environmental efficiency of the regulation and protective structures and fastenings of small rivers have been studied;

- the alluvial regime of rivers, zones of fish migration and spawning have been studied;

- the flood regimes of small rivers and regulation methods have been studied;

- the efficiency of anti-erosion structures and fastenings have been studied;

- the ecological state of tourist base areas and the arrangement of tourist trails have been studied.

The study results showed the need to use biopositive materials and products as engineering anti-erosion measures. The proposed (table 1) bank protection, channel regulation and anti-erosion structures ensure the development of bioengineering systems for protection and restoration of disturbed lands.

There is also a number of similar author's developments on protective and regulatory structures, confirmed by patents for inventions and prepared for application for new patents. Structures of and their construction technologies are biopositive. They provide favorable conditions for fish spawning and germination of green plants in coastal and recreational zones.

\section{Results and Discussion}

The study results and current environmental problems of disturbed lands, as well as the existing experience of controlling natural exogenous processes, make it possible to assess the need for development and implementation of bioengineering systems. Over the past 20 years, some of the new proposed structures, made from local natural materials, have been built and tested in natural conditions on the North Caucasus rivers. The study has shown high reliability and efficiency of these structures. They are overgrown, merged with the environment and continue to perform engineering functions, having transformed in bioengineering (nature-like) structures. Material costs for construction and maintenance are more than 2 times less than traditional reinforced concrete structures.

The preparation of the main technical solutions for the manufacture of prefabricated elements of structures from local materials - sand, vegetable soil, reeds, etc. The use of prefabricated products and structures made of natural materials provides an accelerated restoration of disturbed and eroded land areas. Prefabricated products (wiepped fascine, heavy fascine, flexible mat) serve as the basic elements of bioengineering structures. Using these standard products and elements, various structures are assembled and erected, forming protective and restorative bioengineering systems. These systems will simultaneously perform both engineering and biological tasks.

The most significant results of studies and development include theoretical foundations and technical conditions for the design and construction of bioengineering systems for land restoration and protection. The technical parameters, main criteria, constructive and 
technological connections for the development of bioengineering systems have been determined.

The development and implementation of bioengineering systems ensure high efficiency of conducted flood and erosion control measures to protect and restore disturbed areas. Over time, they turn into biopositive designs, overgrown with shrubs and grass, which help the development of natural processes of restoration of eroded lands.

Table 1. Innovative technical solutions for the development of bioengineering systems.

\begin{tabular}{|c|c|}
\hline $\begin{array}{c}\text { Names and numbers of patents, diagrams of } \\
\text { structures and devices }\end{array}$ & $\begin{array}{l}\text { Summary and purpose of technical } \\
\text { solutions }\end{array}$ \\
\hline $\begin{array}{l}\text { 1. Heavy fascine of biopositive design and its } \\
\text { construction method } \\
\text { Patent No. 2396391 E02B 3/12 dated 08/10/2010; } \\
\text { Patent No. 2369687 E02B 3/12 dated 10/102009 }\end{array}$ & $\begin{array}{l}\text { It is made of bags filled with plant soil and } \\
\text { packed in a shell of wiepped fascines. Then } \\
\text { it is wrapped in a gabion net and tied. It is } \\
\text { designed to create protective structures, } \\
\text { restore slopes and eroded lands under } \\
\text { conditions: } \\
\mathrm{i}<0,01, v_{i}=3-4 \mathrm{~m} / \mathrm{s} \text {, } \\
\qquad \mathrm{Fr}=0.8 \ldots 1.5 \text {. } \\
\text { (i - channel slope } v_{i} \text { - average water flow } \\
\text { rate, } \mathrm{m} / \mathrm{s} ; \mathrm{Fr} \text { - Froude number) }\end{array}$ \\
\hline $\begin{array}{l}\text { 2. The supporting wall of biopositive design and its } \\
\text { construction method } \\
\text { Patent No. 2399717 E02B 3/12 dated 09/20/2009 }\end{array}$ & $\begin{array}{l}\text { The supporting wall is two-stage and is } \\
\text { made of } 3 \text { heavy fascines and } 4 \text { gabion } \\
\text { mats. On the slope above the wall, an } \\
\text { attachment is arranged from } 12 \text { mats made } \\
\text { of } 9 \text { wiepped fascines. It is recommended } \\
\text { for use against collapse and for restoration } \\
\text { of coastal slopes under conditions: } \\
\mathrm{i}=0.005 \ldots 0.01 \\
\qquad \begin{array}{c}v_{i} \\
\mathrm{Fr}\end{array}=2-4 \mathrm{~m} / \mathrm{s} \\
\end{array}$ \\
\hline $\begin{array}{l}\text { 3. The dam dike of biopositive design and its } \\
\text { construction method } \\
\text { Patent No. 2336388 E02 3/06. Bull. No. 29, } 2008 \\
\text { Patent No. 2319805, 2008 }\end{array}$ & $\begin{array}{l}\text { Wooden spatial crib structure } 1 \text { is filled } \\
\text { with gabion mats } 2 \text {. The head of dam dikes } \\
\text { is reinforced with wooden piles } 6 \text {. The } \\
\text { structure is anchored } 8 \text {. It is recommended } \\
\text { for channel regulation and coastline } \\
\text { stabilization under conditions: } \\
\qquad \mathrm{i}=0.0005 \ldots 0.002, \\
\qquad v_{i}=0.5-2 \mathrm{~m} / \mathrm{s} \text { and } \mathrm{Fr}<0.5 \text {. } \\
\text { Experimental studies were performed at the } \\
\text { Terek and Zolka rivers. }\end{array}$ \\
\hline
\end{tabular}


Table 1. Continued.

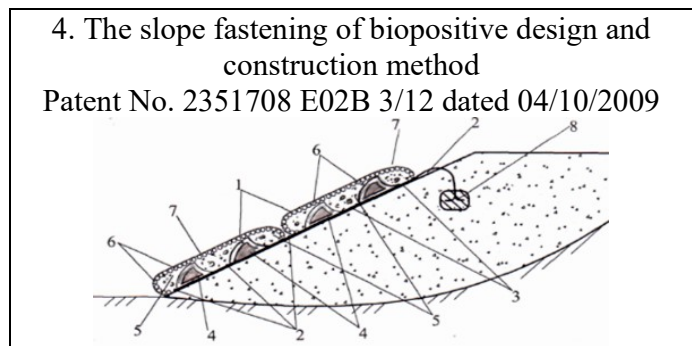

5. The slope fastening of biopositive design fascines and its construction method Patent No. 2399718 E02B 3/12 E02D 17/20; ate 09/20 2010;

Patent No. 2398930, 2010

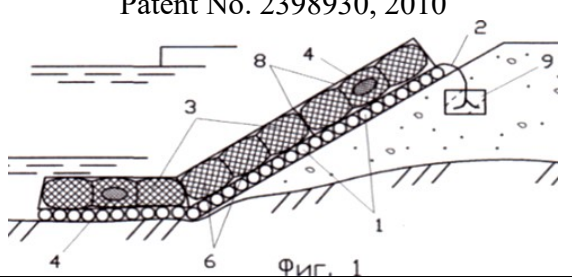

6. Construction of supporting walls from gabions Patent for Invention No. 2336389, 2008

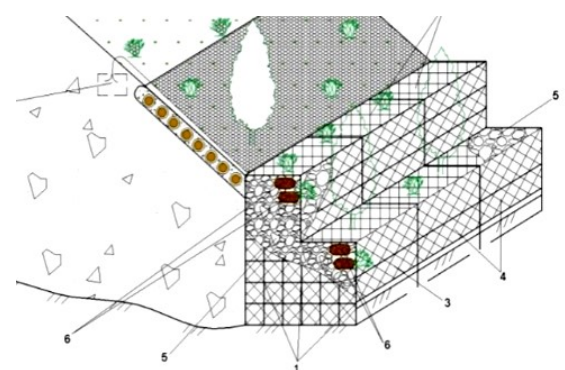

7. Erosion control works of biopositive design and its construction method

Patent for Invention No. 2449078, 2012

Patent for Invention No. 2451129, 2012
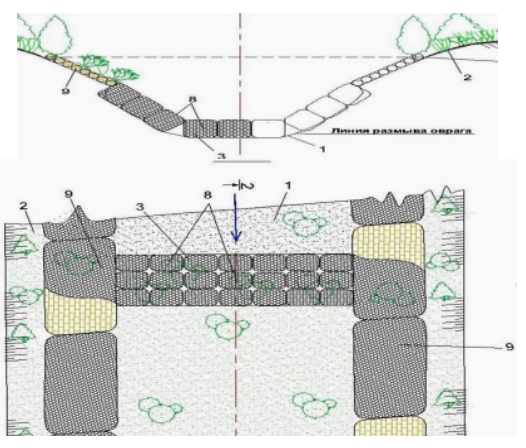

Fastening of interconnected mats 1 and anchored with wires 2 to concrete cubes 8 . Mats in a shell of wiepped reed fascines 6 are filled with local soil 5 and have inclusions in the form of pockets with fertile soil 4 and plant seeds. It is recommended as an erosion control structure.

The fastening layer-by-layer includes a number of reed fascines 1 , a coarse mesh 8 , a number of heavy fascines 3 and on top of a coarse mesh 8 . The meshes are interconnected and tied to anchors 9 with wire. It is designed to protect and restore coastal slopes from erosion when:

$$
\begin{gathered}
\mathrm{i}=0.0005 \ldots 0.015, \\
v_{i}=0.7-4 \mathrm{~m} / \mathrm{s}, \\
\mathrm{Fr}=0.5 \ldots 1.5 .
\end{gathered}
$$

A two-stage supporting wall made of gabions 3 , reinforced with reinforcing cage

1. Gabions have 5 stone filling and 6 inclusions from bags with plant soil. It is recommended to use it against erosion and collapse of slopes under conditions:

$$
\begin{gathered}
\mathrm{i}=0.005 \ldots 0.015, \\
v_{i}=2-4.5 \mathrm{~m} / \mathrm{s}, \\
\mathrm{Fr}=0.5 \ldots 2.0 .
\end{gathered}
$$

Experimental studies were performed at the Cherek and Nalchik rivers

Cross rapids 8 are arranged at the bottom of a ravine of heavy fascines 3 at a certain distance. Above the rapids, the coastal slopes are reinforced with mats 9 made of wiepped fascines 5 and a gabion mesh. It prevents the development of ravines and slope erosion. 
Table 1. Continued.

\begin{tabular}{|c|c|}
\hline $\begin{array}{l}\text { 8. Coastal fastening made of fascines and gabion } \\
\text { mats of biopositive design and its construction } \\
\text { method } \\
\text { Patent for Invention No. } 2565264,2015 \\
\text { Patent for Invention No. } 2569828,2015\end{array}$ & $\begin{array}{l}\text { The fastening is made of interconnected } \\
\text { heavy fascines, laid in longitudinal and } \\
\text { transverse rows to form square cells. The } \\
\text { cells in one layer are packed with wiepped } \\
\text { fascines in dense rows and covered with a } \\
\text { gabion mesh. Under the slope, gabion mats } \\
\text { of a prismatic shape are arranged, covered } \\
\text { with segmental-shaped reinforcing lattice } \\
\text { frames and attached to anchors using cables } \\
\text { or wire. } \\
\text { It is recommended to protect river banks } \\
\text { from erosion and destruction. }\end{array}$ \\
\hline $\begin{array}{l}\text { 9. Heavy fascine of flexible design } \\
\text { Utility model patent No. } 183818,2019\end{array}$ & $\begin{array}{l}\text { The fascines are made of bags filled with } \\
\text { local soil mixed with dry vegetation, } \\
\text { wrapped in two layers of geomat, tied in } \\
\text { several places with wire. They can be laid } \\
\text { in rows on a prepared bank slope, tied } \\
\text { together, anchored and secured. }\end{array}$ \\
\hline $\begin{array}{l}\text { 10. Supporting walls are used to protect the coastal } \\
\text { areas of rivers from collapse and erosion and their } \\
\text { construction method } \\
\text { Patent for Invention No. 2645334, } 2018\end{array}$ & $\begin{array}{l}\text { The coastal anchorage contains two types of } \\
\text { supporting walls, one on top of the other. } \\
\text { The first wall is two-stage } 1 \text { and } 2 \text {, made of } \\
\text { heavy fascines } 3 \text { and gabion mats } 4 \text {. } \\
\text { The second supporting wall is a stepped } \\
\text { reinforced soil structure. It is made of } 4 \\
\text { gabion mats with drains } \\
\text { and reinforced soil mass. It is recommended } \\
\text { to protect coastal zones from collapse and } \\
\text { erosion. }\end{array}$ \\
\hline 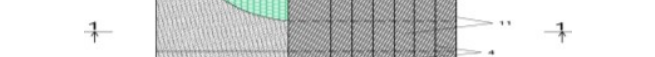 & \\
\hline
\end{tabular}

\section{Conclusions}

1. Technical conditions and recommendations for implementation of bioengineering systems into the practice of water management and environmental construction have been developed.

2. Based on study results, the efficiency and reliability of proposed bioengineering structures for foothill and flat areas of small rivers have been confirmed.

3. More effective methods for the manufacture of biopositive products from natural materials and the accelerated construction of protective and regulatory structures have been proposed.

4. The technological connections and conditions for the layout and binding of structures and fastenings for the foothill and mountain zones of small rivers have been determined and refined. 
5. New effective ways of fastening coastal slopes, protection and restoration of disturbed lands in accordance with environmental technologies have been confirmed by patents.

The development and implementation of bioengineering systems into the practice of water management and environmental construction will effectively solve the problems of engineering protection and environmental management of disturbed land areas.

In the future, based on the results of the implementation of new constructive and technological solutions, the main technical parameters, criteria and constructive and technological connections for the development of bioengineering systems of protective and regulatory structures on protected and restored land areas will be found and determined.

In conclusion, based on study results, scientifically grounded technical conditions will be developed for the regulation of sections of small rivers, the design and construction of environmentally effective structures for protective, regulatory and anti-erosion structures.

\section{References}

1. D. L. Armand, Agricultural Erosion and Control (2009)

2. J. M. Anderson, Ecology and Environmental Sciences: Biosphere, Ecosystems, Man (1985)

3. V. P. Bondarev, Geomorphological Analysis and Forecast of Gullying (2010)

4. T. K. Bykovskaya, T. A. Paramonova, Bulletin of Moscow State University, 17 (2), 814 (1998)

5. K. S. Losev, I. I. Mazur, R. G. Mamin, Natural Resources, Nature Reserves and International Environmental Problems (2009)

6. S.V. Krivitskiy, Bulletin of Moscow State Construction University, 4, 285-290 (2009)

7. B. Nebel, Environmental Science: The Way the World Works (1993)

8. Yu. Odum, Ecology (1986)

9. S. O. Kurbanov, A. A. Sozaev, Ecology and Industry of Russia, 24 (8), 34-39

10. S. O. Kurbanov, A. A. Sozaev, T. M. Chapaev, Proceedings of the int. scientificpractical conference, 268-278 (2020)

11. S. O. Kurbanov, S. M. Zhemgurazov, Zh. H. Nastaeva, Polythematic Network Electron ic Scientific J. of the Kuban State Agrarian University, 149 (5) (2019)

12. S. O. Kurbanov, A. A. Sozaev, Polythematic Network Electronic Scientific J. of the Kuban State Agrarian University, 118, 916-936 (2016)

13. S. O. Kurbanov, E. A. Kushaeva, M. M. Khasanov, Electronic scientific J. "Engineerin g Bulletin of the Don", 4 (2017)

14. S. O. Kurbanov, A. A. Sozaev, “Applied Scientific News-2014”: Materials X Int. Scientific-Practical Conf., 40-43 (2014)

15. S. O. Kurbanov, A. A. Sozaev, A. B. Balkizov, T. M. Chapaev, Science Education Practice: proceedings of the Int. University Science Forum, 117-130 (2020)

16. S. O. Kurbanov, A. A. Sozaev, M. M. Shakhmurzov, Method of Erosion Control Const ruction of Biopositive Design, 1, 8

17. S. O. Kurbanov, K. S. Kurbanov, The method of manufacturing heavy fascines of biopositive construction, $\mathbf{8}, 8$

18. S. O. Kurbanov, A. A. Sozaev, Gabion mat of biopositive design, 28, 7 
19. S. O. Kurbanov, F. T. Dudarova, The construction method of a slope fastening of a bipositive design, 9, 6

20. S. O. Kurbanov, F. A. Srukhova, The construction method of an anti-erosion biopositiv e design for gully restoration, 29, 7

21. S. O. Kurbanov, A. A. Sozaev, D. V. Dulaeva, The construction method of a coastal fastening from bipositive fascines, 33, 6

22. S. O. Kurbanov, S. M. Zhemgurazov, M. M. Khasanov, Gabion mat of flexible design, 11, 6

23. S. O. Kurbanov, A. A. Sozaev, F. T. Dudarova, Construction of supporting walls for riverbank protection against collapse and erosion, 6, 6

24. S. O. Kurbanov, A. A. Sozaev, E. A. Kushaeva, Heavy fascine of flexible design, 28, 6 